\title{
BIBLIOGRAPHY OF ELIZABETH C. CROSBY
}

\author{
compiled by \\ EDWARD W. LAUER AND JOSHUA H. CAREY \\ Department of Anatomy, Dniversity of Michigan and \\ Departments of Pediatrics and Neurology, University of Buffalo
}

1. The forebrain of Alligator mississippiensis. J. Comp. Neur., 27: 325-402, 1917.

2. (With C. Judson Herrick) A laboratory outline of neurology. W. B. Saunders Co., Philadelphia and London. 1918. Second edition. 1920.

3. (With G. Carl Huber) On thalamic and tectal nuclei and fiber paths in the brain of the American alligator. J. Comp. Neur., 40:97-227, 1926.

4. (With G. Carl Huber) Somatic and visceral connections of the diencephalon. Arch. Neurol. and Psychiat., $\mathscr{Q} \mathscr{R}:$ 187-229, 1929. Reprinted in: The vegetative nervous system. Res. Publ. Ass. Nerv. Ment. Dis., 9: 199-248. The Williams and Wilkins Co., Baltimore. 1930.

5. (With G. Carl Huber) The nuclei and fiber paths of the avian diencephalon, with consideration of telencephalie and certain mesencephalie centers and connections. J. Comp. Neur., 48: 1-225, 1929.

6. (With G. Carl Huber) A phylogenetic consideration of the optic tectum. Proc. Nat. Acad. Sci., 19: 15-22, 1933.

7. (With G. Carl Huber) The reptilian optic tectum. J. Comp. Neur., 57: 57-163, 1933.

8. (With G. Carl Huber) The influences of afferent paths on the cytoarchitectonie structure of the submammalian optic tectum. Feestbundel aan Prof. C. U. Ariëns Kappers. Psychiat. en Neurol. B1., pp. 459474, 1934 .

9. Huber, G(otthelf) Carl. The Nat. Cyelo. Amer. Biog., Current, D: 274, 1934.

10. (With C. U. Ariëns Kappers and G. Carl Huber) The comparative anatomy of the nervous system of vertebrates, ineluding man. 2 vol. The Macmillan Co., New York. 1936.

11. (With A. C. Furstenberg and D. Brownell) Hypertensive deafness. Trans. Amer. Otol. Soc., 27: 221-239, 1937.

12. (With Tryphena Humphrey) The human olfactory bulb. Univ. (Mich.) Hosp. Bull., 4: 61-62, 1938.

13. (With Russell T. Woodburne) Certain major trends in the development of the efferent systems of the brain and the spinal cord. Univ. (Mich.) Hosp. Bull., 4: 125-128, 1938.

14. (With Tryphena Humphrey) The accessory olfactory bulb in phylogeny. Anat. Rec., 7O (suppl.): 19, 1938. 
15. (With Tryphena Humphrey) A comparison of the olfactory and the accessory olfactory bulbs in certain representative vertebrates. Papers Mich. Acad. Sci. Arts \& Letters, 24 (part 2) : 95-104, 1939.

16. (With Tryphena Humphrey) Studies of the vertebrate teleneephalon. I. The nuclear configuration of the olfactory and accessory olfactory formations and the nueleus olfactorius anterior of certain reptiles, birds and mammals. J. Comp. Neur., 71: 121-213, 1939.

17. (With Russell T. Woodburne) The comparative anatomy of the preoptic area and the hypothalamus. Res. Publ. Ass. Nerv. Ment. Dis., 20: 52-169. The Williams and Wilkins Co., Baltimore. 1940.

18. (With Tryphena Humphrey) Studies of the vertebrate telencephalon. II. The nuclear pattern of the anterior olfactory nucleus, tuberculum olfactorium and the amygdaloid complex in adult man. J. Comp. Neur., 74: 309-352, 1941.

19. (With A. C. Furstenberg and B. Farrior) Neurologieal lesions which influence the sense of smell. Trans. Amer. Laryng. Rhin. Otol. Soe., $48: 40-55,1942$.

20. (With G. Carl Huber) The mammalian midbrain and isthmus regions. Part I. The nuclear pattern. A comparison of the mammalian and reptilian tecta. J. Comp. Neur., 78: 133-168, 1943.

21. (With Russell T. Woodburne) The mammalian midbrain and isthmus regions. Part I. The nuclear pattern. The nuclear pattern of the non-tectal portions of the midbrain and isthmus in the armadillo. J. Comp. Neur., 78: 191-211, 1943.

22. (With Russell T. Woodburne) The mammalian midbrain and isthmus regions. Part I. The nuclear pattern. The nuclear pattern of the nontectal portions of the midbrain and isthmus in the shrew and the bat. J. Comp. Neur., 78: 253-288, 1943.

23. (With Russell T. Woodburne) The mammalian midbrain and isthmus regions. Part I. The nuclear pattern. The nuclear pattern of the nontectal portions of the midbrain and isthmus in primates. J. Comp. Neur., 78: 441-482, 1943.

24. (With Russell T. Woodburne) The mammalian midbrain and isthmus regions. Part I. The nuclear pattern. Discussion of the literature. J. Comp. Neur., 78: 483-503, 1943.

25. (With Russell T. Woodburne) The mammalian midbrain and isthmus regions. Part I. The nuclear pattern. General summary. J. Comp. Neur., 78: 505-520, 1943.

26. (With Tryphena Humphrey) Studies of the vertebrate telencephalon. III. The amygdaloid complex in the shrew (Blarina brevicauda). J. Comp. Neur., 81: 285-305, 1944.

27. (With A. C. Furstenberg) Disturbance of the function of the salivary glands. Ann. Otol. Rhin. Laryng., 54: 243-264, 1945.

28. Cornelius Ubbo Ariëns Kappers. J. Comp. Neur., 85: 308-311, 1946. 
29. (With Russell T. Woodburne and Rollo E. McCotter) The mammalian midbrain and isthmus regions. Part II. The fber connections. A. The relations of the tegmentum of the midbrain with the basal ganglia in Macaca mulatta. J. Comp. Neur., 85: 67-92, 1946.

30. (With Russell T. Woodburne) The phylogenetie development of the vertebrate nervous system. Encyclopaedia Brittanica. 1948.

31. (With John W. Henderson) The mammalian midbrain and isthmus regions. II. Fiber connections of the superior colliculus. B. Pathways concerned in automatic eye movements. J. Comp. Neur., 88: 53-92, 1948.

32. (With A. C. Furstenberg) Neuron ares of clinical significance in laryngology. Ann. Otol. Rhin. Laryng., 57: 298-310, 1948.

33. Book review of The Brain of the Tiger Salamander by $\mathrm{C}$. Judson Herrick. Amer. Midland Nat., 41: 255, 1949.

34. The application of neuroanatomical data to the diagnosis of selected neurosurgical and neurological cases. J. Neurosurg., 7: 566-583, 1950.

35. (With Russell T. Woodburne) The mammalian midbrain and isthmus regions. II. The fiber connections. C. The hypothalamo-tegmental pathways. J. Comp. Neur., 94: 1-32, 1951.

36. (With Richard C. Schneider and Edgar A. Kahn) Extradural hematoma of the posterior fossa. Neurol., 1: 386-393, 1951.

37. (With Russell T. Woodburne) Neuroanatomy. In Progress in Neurology and Psychiatry, 7: 1-12. Edited by E. A. Spiegel. Grune and Stratton, New York. 1952.

38. (With John W. Fenderson) An experimental study of optokinetie responses. A. M. A. Arch. Ophthal., 47: 43-54, 1952.

39. (With Robert E. Yoss and John W. Henderson) The mammalian midbrain and isthmus regions. Part II. The fiber connections. D. The pattern for eye movements on the frontal eye field and the diseharge of specific portions of this field to and through midbrain levels. J. Comp. Neur., 97: 357-383, 1952.

40. A diseussion of certain cortical areas related to eye deviations. Centennial Celebration of Cajal, Madrid, Spain. Nov., 1952.

41. Relations of brain centers to normal and abnormal eye movements in the horizontal plane. J. Comp. Neur., 99: 437-479, 1953.

42. Nystagmus as a sign of central nervous system involvement. Ann. Otol. Rhin. Laryng., 62: 1117-1127, 1953.

43. (With Russell T. Woodburne) Neuroanatomy. In Progress in Neurology and Psychiatry, 8: 1-13. Edited by E. A. Spiegel. Grune and Stratton, New York. 1953.

44. Jean Nageotte (1866-1948). In The Founders of Neurology, pp. 68-70. Edited by W. Haymaker and $K$. A. Baer. Charles C Thomas, Springfield. 1953.

45. (With Richard C. Schneider) Stimulation of "second" motor areas in the macaque temporal lobe. Neurol., 4: 612-622, 1954. 
46. (With Russell T. Woodburne) Neuroanatomy. In Progress in Neurology and Psychiatry, 9: 1-15. Edited by E. A. Spiegel. Grune and Stratton, New York. 1954.

47. (With Robert E. Yoss) The phylogenetic continuity of neural mechanisms as illustrated by the spinal tract of $\mathrm{V}$ and its nucleus. Res. Publ. Ass. Nerv. Ment. Dis., 33: 174-208. The Williams and Wilkins Co., Baltimore, 1954.

48. (With Russell T. Woodburne) Neuroanatomy. In Progress in Neurology and Psychiatry, 10:1-15. Edited by E. A. Spiegel. Grune and Stratton, New York. 1955.

49. (With J. F. R. Fleming) The parietal lobe as an additional motor area. The motor effects of electrical stimulation and ablation of cortical areas 5 and 7 in monkeys. J. Comp. Neur., 103: 485-512, 1955.

50. (With Edgar A. Kahn, R. C. Bassett and R. C. Sehneider) Correlative Neurosurgery. Charles C Thomas, Springfield. 1955.

51. The anatomy of the occipital lobe and the comparative anatomy of the visual pathway. Semaine Neuro-Physiologiques de la Saltpêtrière, Paris, France, Oct., 1955.

52. (With Edward W. Lauer) Neuroanatomy. In Progress in Neurology and Psychiatry, 11: 484-501. Edited by E. A. Spiegel. Grune and Stratton, New York. 1956.

53. The role of the midbrain as a part of the discharge paths from higher centers. In Progress in Neurobiology. Proc. First Int. Meet. Neurobiologists, Groningen, Aug. 3-7, 1955, pp. 217-231. Edited by J. Ariëns Kappers. Elsevier Pub. Co., Amsterdam, London, New York. 1956.

54. (With Edward W. Laver) Neuroanatomy. In Progress in Neurology and Psychiatry, 12: 1-17. Edited by E. A. Spiegel. Grune and Stratton, New York. 1957.

55. (With Mary Jane C. Showers) Somatic and visceral responses from the cingulate gyrus. Neurol., 8: 561-565, 1958.

56. (With Edward W. Lauer) Neuroanatomy. In Progress in Neurology and Psychiatry, 13: 484-500. Edited by E. A. Spiegel. Grune and Stratton, New York. 1958.

57. (With Tryphena Humphrey and Mary Jane C. Showers) Einige Anordungen, Verbindungen und Funktionen der supplementären motorischen Rinden. Ergebnisse der medizinisehen Grundlagenforschung. Edited by Dr. Bauer. Georg Thieme, Stuttgart. In press.

58. (With Edward W. Lauer) Neuroanatomy. In Progress in Neurology and Psychiatry, 14: Edited by E. A. Spiegel. Grune and Stratton, New York. In press.

59. (With Edward W. Lauer) Anatomy of the midbrain. In Introduction to Stereotaxis, with an Atlas of the Human Brain. Edited by $\mathbf{P}$. Bailey and G. Schaltenbrand. Georg Thieme, Stuttgart. In press.

60. (With Tryphena Humphrey and Edward W. Lauer) Correlative anatomy of the nervous system. A textbook of neuroanatomy, nearing completion. 